\title{
KAJIAN PUSTAKA MENGENAI RESTAURANT ATMOSPHERE
}

\author{
Adeline Agoes; Nami Fitricia Pasaribu \\ Hotel Management Department, Faculty of Economic and Communication, BINUS University \\ Jln. K.H. Syahdan No. 9, Palmerah, Jakarta Barat 11480, \\ adeline.agoes@binus.edu; nfitricia@binus.edu
}

\begin{abstract}
Restaurant is one of the businesses that support tourism development. Restaurants nowadays don't only provide food, but also the service and atmosphere to their customers. The purpose of this study is to discover the aspects defining restaurant atmosphere and the implications of restaurant atmosphere to other particular aspects related to restaurant business. This article is written based on a study conducted through a literature review. Through the examination, it is found that the atmosphere of a restaurant is one important aspect and can be considered as a competitive advantage as well as one of the determinants of customer satisfaction.
\end{abstract}

Keywords: restaurant, atmosphere, tourism, competitive advantage, customer satisfaction

\begin{abstract}
ABSTRAK
Restoran merupakan salah satu bidang usaha yang mendukung perkembangan industri pariwisata. Restoran sekarang ini sudah tidak hanya menjual makanan saja, melainkan pelayanan juga suasana yang dapat diberikan kepada para pelanggannya.Tujuan dari penelitian yang akan dilakukan oleh penulis adalah untuk mengetahui aspek-aspek yang dapat mendefinisikan suatu atmosphere dari restoran serta implikasi dari atmosphere dari restoran tersebut untuk aspek lain yang terkait dengan sebuah usaha restoran.Artikel ini ditulis dari sebuah rancangan penelitian yang ditelaah melalui kajian pustaka.Dari hasil pengkajian, didapatkan hasil bahwa atmosphere dari sebuah restoran merupakan unsur penting yang dapat diperhitungkan sebagai competitive advantage serta salah satu penentu kepuasan pelanggan.
\end{abstract}

Kata kunci: restoran, atmosphere, pariwisata, competitive advantage, kepuasan pelanggan 


\section{PENDAHULUAN}

Pariwisata merupakan sebuah industri yang memiliki potensi pertumbuhan lebih tinggi dari sektor-sektor ekonomi yang lain. UNWTO memprediksikan bahwa peningkatan industri pariwisata dunia mencapai 3\% hingga 4\% di tahun 2013 ini. Sejak tahun 2005, industri pariwisata telah menciptakan lapangan kerja bagi 305 juta orang dan menghasilkan 11,4\% dari total pendapatan kotor dunia (UNWTO, 2013). Usaha pariwisata yang terus mengalami peningkatan tersebut seiring dengan meningkatnya ragam permintaan manusia terhadap kegiatan wisata serta tingkat kejenuhan yang dirasakan semakin tinggi terhadap aktivitas sehari-hari manusia. Berbagai usaha pariwisata diciptakan guna memenuhi perubahan yang terjadi dalam perilaku masyarakat. Sebagai salah satu sektor yang mampu memberikan kepuasan bagi konsumennya, pariwisata juga mampu memberikan kontribusi positif bagi pemerintah, pengelola usaha pariwisata, masyarakat lokal maupun lingkungan di sekitar usaha jasa tersebut.

Prioritas perkembangan yang terjadi terfokuskan pada empat komponen produk yaitu atraksi, fasilitas, aksesibilitas dan citra, serta bidang-bidang usaha yang terkait dengan komponen produk tersebut. Pengembangan usaha pariwisata akan memberikan peluang bagi pihak yang sedang atau akan bergerak di sektor pariwisata untuk lebih dapat berkreasi hingga menjadikan usaha yang inovatif, unik dan menarik. Berdasarkan pernyataan diatas, dapat dikatakan bahwa pariwisata memiliki peranan yang strategis di masa mendatang dan diharapkan akan mampu berfungsi sebagai lokomotif pendorong ekonomi negara maupun bagi unit usaha itu sendiri.

Dalam Sujatno (2011) dikatakan bahwa restoran berasal dari bahasa Perancis yaitu restoratives yang berati obat yang menyegarkan dengan harapan dapat memberikan penyegaran bagi orang banyak. Kata tersebut menimbulkan imajinasi dan melahirkan banyak ide guna menarik pasar, yang pada akhirnya menjadi bisnis yang dinamis dengan variasi dan keunikan masing-masing. Restoran merupakan salah satu bidang usaha yang mendukung perkembangan industri pariwisata. Restoran sekarang ini sudah tidak hanya menjual makanan saja, melainkan pelayanan juga suasana yang dapat diberikan kepada para pelanggannya. Menurut Walker (2009), restoran memiliki peran penting dalam gaya hidup manusia sebagai bagian dari aktivitas sosial mereka. Hal ini selaras dengan ungkapan Peck (2008) yang secara menarik mengungkapkan "if the only thing to purchase at a restaurant were food, it would be called a grocery store". Apabila diartikan, sebuah restoran tidak akan ada bedanya dengan toko swalayan apabila satu-satunya hal yang bisa didapatkan adalah makanan saja.

Walker (2009) menyatakan bahwa selain perencanaan menu, dalam mengembangkan sebuah usaha restoran terdapat lima hal yang perlu diperhatikan, yaitu operating philosophy, market, concepts, location, dan ambiance atau atmosphere. Hal ini menunjukkan bahwa restaurant atmosphere merupakan bagian penting dari sebuah usaha restoran yang tidak dapat dihilangkan. Walker (2009) lebih menjelaskan bahwa restaurant atmosphere atau suasana restoran merupakan efek seketika yang diberikan sebuah restoran kepada para pelanggannya baik secara disadari atau tidak.

Banyak sekali pendapat yang menyatakan bahwa restaurant atmosphere merupakan hal lain yang dipertimbangkan selain makanan. Seorang ahli lain adalah Robson (2013) yang mengatakan bahwa desain restoran dapat mempengaruhi keputusan pembelian dan pembeli akan melakukan transaksi berdasarkan dorongan emosi daripada dorongan rasional. Robson (2013) juga mengemukakan bahwa pelanggan yang datang ke restoran tidak hanya ingin makan diluar rumah, namun saat ini riset psikologi menemukan bahwa motivasi individu untuk melakukan makan diluar adalah untuk melakukan sosialisasi, untuk melakukan relaksasi dan melakukan eksperimen, Maka dari itu, sebuah desain restoran yang efektif dapat memberikan pemenuhan kebutuhan khusus tersebut. Hashim (2011) menyimpulkan dari sudut pandang para penyedia layanan bahwa lingkungan fisik dan 
harga yang wajar merupakan dua esensi penting yang menentukan kepuasan pelanggan yang hasil akhirnya loyalitas pelanggan.

Mueller (2001) sebelumnya juga mengemukakan bahwa kondisi lingkungan restoran saat ini merupakan hal yang penting, disamping makanan yang enak dan pelayanan yang cepat. Dengan gaya hidup yang sibuk dan serba cepat, tingkat pertumbuhan makanan yang dikonsumsi di luar rumah pun meningkat, banyak individu hanya medapatkan jam istirahatnya di saat sedang makan. Dengan demikian, restoran kini memberikan kenyamanan dengan atmosfir yang memberikan ketenangan, kesegaran dan relaksasi. Warna merupakan kontributor yang kuat untuk menciptakan suasana dan aura yang diinginkan. Sedangkan cahaya adalah elemen yang memberikan keunikan pada tempat (Mueller, 2001).

Dalam Hashim (2011), Turley dan Milliman (2000) menyatakan bahwa yang termasuk dalam atmosphere adalah tampilan, suara, aroma dan sentuhan yang biasa disebut sebagai "ambience". Sedikit berbeda dengan Parpal (2013) yang menjabarkan bahwa atmosfir merupakan salah metode terpenting untuk menciptakan konsep pada restoran. Atmosfir restoran secara keseluruhan adalah rasa, pemandangan, pencahayaan, warna, proses pengolahan makanan, suara, dan music. Rasa (taste) yang dimaksud adalah rasa yang dihasilkan dari produk makanan yang disajikan dan pemandangan (sight) adalah konsep dari apa yang akan dilihat oleh pelanggan. Pencahayaan (lighting) dapat mempengaruhi suasana hati pelanggan serta suasana secara keseluruhan, sedangkan warna (color) pada restoran dimaksudkan untuk membangkitkan perasaan tertentu dan sebagai pembangkit selera makan. Proses pengolahan makanan (cooking process) dijelaskan apakah proses memasak dapat dilihat atau tidak oleh pelanggan Suara (sound) merupakan bunyian yang terdengar di restoran yang dapat memberikan efek terhadap atmosfir, sedangkan musik (music) dikatakan dapat memberikan pengaruh pada atmosfir (Parpal, 2013).

Ramapuram (2006) menentukan atribut yang harus dimiliki oleh sebuah restoran seperti tertulis pada Tabel 1 berikut ini:

Tabel 1 Restaurant Attributes

\begin{tabular}{llll}
\hline \multicolumn{1}{c}{ Atmosphere } & \multicolumn{1}{c}{ Convenience } & \multicolumn{1}{c}{ Service } & \multicolumn{1}{c}{ Food } \\
\hline Level of comfort & Handling of telephone & Speed/ efficiency of service & Presentation of food \\
Level of noise & Location/ accessibility & Friendly/ polite, helpfull staff & Menu item variety \\
View from restaurant & Opening/ closing hours & attentiveness of staff & Nutrious food \\
Overall cleanliness & Parking facilities & Food/ beverages knowledge of staff & Tastiness of food \\
Restaurant appearance & & & Freshness of food \\
& & & Temperature of food \\
\hline
\end{tabular}

Sumber: Ramapuram, 2006

Lebih sederhana dari pernyataan Parpal (2013), Ramapuram (2006) menentukan bahwa restaurant atmosphere terdiri dari level of comfort, level of noise, view from restaurant, overall cleanliness, dan restaurant appearance. Finkelstein (1989) dan Wood (1995) dalam Ramapuram (2006) memperdebatkan apakah secara kolektif atribut-atribut di atas akan memberikan identitas dan karakter pada restoran sehingga mempengaruhi pelanggan dalam membeli dan kembali lagi. Namun Ramapuram (2006) menegaskan bahwa pada studi terkini, keinginan kembali atau tidak merupakan ukuran behavior sebagai variabel dependen sedangkan atribut restoran adalah variabel independennya. Sehingga membawa penelitian ini untuk menilik, keinginan dan kebutuhan pelanggan seperti apa yang akan dipenuhi, apa pesan yang ingin disampaikan melalui desain interior dan atmosfir kepada pelanggan, bagaimana seorang pengusaha restoran menyikapi dan melihat tren yang akan diusung pada desain restoran yang akan memberikan keuntungan. 
Terdapat banyak sekali konsep yang mengupas tentang atmosfir dari sebuah restoran. Oleh sebab itu, dalam kesempatan kali ini penulis akan menelaah lebih jauh mengenai atmosphere dari sebuah restoran, diantaranya aspek apa saja yang dapat mendefinisikan suatu atmosphere, serta implikasi yang dapat terlihat dari restaurant atmosphere.

\section{METODE}

Penelitian ini diawali oleh observasi dari beberapa restoran di Jakarta yang memiliki beragam suasana untuk ditawarkan. Sejauh ini, penulisan artikel masih dibuat sebagai sebuah rancangan penelitian melalui kajian pustaka untuk mengetahui aspek apa saja yang dapat mendefinisikan suatu atmosphere dan implikasi apa saja yang dapat terlihat dari restaurant atmosphere untuk aspek-aspek lain yang terkait dengan sebuah usaha restoran. Kajian pustaka dilakukan melalui ulasan beberapa textbook dan artikel ilmiah yang terkait.

\section{HASIL DAN PEMBAHASAN}

Atmosphere atau suasana dari sebuah restoran merupakan salah satu aspek operasional yang sulit untuk didefinisikan. Namun demikian, atmosphere seringkali diartikan sebagai sebuah bentuk 'rasa' di dalam sebuah restoran (Davis et al., 2008). David et. al. (2008) juga menambahkan bahwa atmosphere dari sebuah restaurant dapat dipengaruhi oleh berbagai aspek operasional, yaitu, pengaturan kursi dan meja, pelayanan tambahan, pakaian dan perilaku para staf, tempo dari pelayanan, usia, pakaian dan jenis kelamin para pelanggan lain, tingkat suara di dalam restoran, apakah terdapat musik yang dimainkan, temperatur, dan kebersihan serta profesionalisme dari staf secara keseluruhan. Atmosphere dan lingkungan dari sebuah jenis usaha penyedia makanan dan kemampuan sosial dari para staf dapat menjadi daya tarik tertentu untuk beberapa pelanggan (Davis et al., 2008). Pengertian lain dari atmosphere juga diutarakan oleh Katsigris dan Thomas (2009) sebagai mood dari restoran secara keseluruhan dan dengan kata lain dapat diartikan sebagai ambiance atau energy.

Katsigris dan Thomas (2009) mengatakan bahwa masih terdapat banyak perdebatan mengenai apakah penampilan dan 'rasa' dari sebuah restoran dapat mempengaruhi kesuksesannya sebagai sebuah tempat untuk menikmati makanan. Tetap saja pada akhirnya elemen yang paling penting adalah makanan dan pelayanan. Namun demikian, penampilan dan 'rasa' dari sebuah restoranlah yang mengundang pelanggan untuk masuk (Katsigris dan Thomas, 2009). Katsrigis dan Thomas (2009) juga menambahkan bahwa kata 'kenyamanan' seringkali diasosiasikan dengan atmosphere. Tentunya, arti kenyamanan berbeda untuk setiap orang. Temperatur ruangan, desain dari busa untuk sofa, selera pribadi untuk memilih booth dan bukan meja, kesan untuk privasi atau keterbukaan, jarak ke tempat makan yang lain, kemampuan restoran untuk memisahkan ruangan untuk dewasa dan anak-anak, serta aksesibilitas untuk pelanggan yang memiliki keterbatasan secara fisik hanya merupakan beberapa hal yang perlu dipertimbangkan. Ketidaknyamanan hampir selalu dikaitkan dengan atmosphere yang didesain secara kurang baik (Katsrigis dan Thomas, 2009). Gambar 1 berikut ini merupakan bentuk kepedulian terhadap atmosphere yang dipaparkan oleh Katsigris dan Thomas (2009): 


\section{Atmosphere Awareness}

Vision. Exterior signage and facade; high or low light levels; bright or subdued colors; use of mirrors or partitions (either portable or fixed) to expand or reduce space; height of ceilings; menu design; artwork on walls; window coverings; positioning of tables.

Touch. Floors of marble, tile, carpet, or wood; chairs of wood, metal, leather, or fabric; seats cushioned or not cushioned; table linens or bare surfaces; chunky or dainty glassware; baskets or plastic plates, earthenware, or fine china; plastic tableware, stainless steel, or silver flatware; paper on which the menu is printed.

Sound. Loud or subdued conversation; type and loudness of music, live or on the sound system; dishes being bussed; kitchen or bar noise; hum of central heat or air-conditioning system; cash registers; street noise from outside.

Smell. Aromas of baking or spices; rancid odor of fryer oil that needs changing; colognes of guests and staff; wood in fireplace; "new" smells of carpet, fabrics, or linens; restroom air fresheners.

Taste. A cool drink; a fluffy soufflé; a crisp onion ring; a perfectly cooked steak; a hot curried dish.

Temperature. The thermostat setting of a room; body heat of guests and staff; heat from the kitchen or coffee station; breeze created by ceiling fans; breeze when seated directly above (or below) a vent or open window; direct sunlight or use of window coverings; hot food served hot; cold food served cold.

Motion. The effort it takes to get to a table or chair; the way servers negotiate the dining room with trays; the waiting line as perceived by passersby (and people still dining); activity within the dining room as viewed through windows; outside activity as viewed by diners.

Gambar 1 Atmosphere Awareness (Katsigris dan Thomas, 2009)

Gambar 1 di atas menjelaskan bahwa untuk menunjukkan kepedulian terhadap atmosphere didalam sebuah restoran, aspek-aspek yang perlu diperhatikan adalah aspek visual, raba, suara, aroma, rasa, temperatur, dan gerakan. Apabila dilihat secara singkat, selain temperatur dan gerakan dari aktifitas di dalamnya, atmosphere dari sebuah restoran harus mampu dinikmati oleh seluruh indera manusia.

Sebuah studi mengenai penerapan atmosphere sebuah restoran dilakukan oleh Kenkman dan Hooper (2012). Studi ini dilakukan dimana pengalaman makan untuk para penghuni panti wreda dieksplorasi lebih jauh. Penelitian dilakukan dimana fasilitas makan di empat panti wreda di Norfolk, Inggris, dibentuk menyerupai restoran atau restaurant-style, kemudian dibandingkan dengan fasilitas makan yang ada saat ini. Chao et al. (2008) dalam Kenkman dan Hooper (2012) menyatakan bahwa hingga saat ini tidak ada kesepakatan diantara para ahli mengenai fasilitas makan yang ideal untuk panti wreda. Dalam studi yang serupa sebelumnya, intervensi untuk fasilitas tempat makan pernah dilakukan dengan membentuk suasana makan lebih seperti family-style atau lebih fokus mempertimbangkan perbaikan kualitas dari sisi gizi (Kenkman dan Hooper, 2012). Latar belakang penerapan intervensi dalam studi ini adalah untuk mengurangi 'rasa ditempatkan dalam suatu lembaga' dengan menambahkan lebih banyak pilihan, akses terhadap makanan dan minuman yang lebih baik dan lebih banyak untuk para penghuni pantiserta peningkatan atmosphere saat waktu makan.

Pembentukan fasilitas makan yang menyerupai restoran juga berarti bahwa para penghuni panti wreda dapat lebih fleksibel dan percaya diri dalam mengundang para teman dan keluarga untuk bergabung dengan mereka pada waktu makan. Hal ini berarti memperlebar kesempatan mereka untuk berinteraksi dengan kerabat dan orang luar. Landasan ide restoran ini adalah bahwa para penghuni panti wreda juga dapat memilih dengan siapa mereka ingin duduk, duduk dan bercakap-cakap lebih lama, sehingga memperluas jaringan pertemanan mereka (Kenkman dan Hooper, 2012). Cassolato et al. (2010) dalam Kenkman dan Hooper (2012) berargumen bahwa makan dilingkungan restoran akan menstimulasi fungsi kognitif dan mendukung keluarga dan teman untuk memiliki 'waktu bersama yang terfokus'. Karenanya, makanan yang dipresentasikan secara baik serta atmosphere yang ramah 
dan santai dapat memberikan kontribusi terhadap pengalaman positif yang luas dimana hal ini dapat bekerja dengan baik dari sekedar asupan nutrisi.

Para penghuni panti wreda dalam penelitian ini memberikan apresiasi terhadap peningkatan atmosphere saat makan. Restoran yang baru tersebut terlihat mampu meningkatkan sosialisasi antar penghuni juga dengan kerabat dan teman. Perubahan yang terkait juga meningkatkan kepuasan dari sisi variasi menu makanan, selain apresiasi terhadap dekor dan atmosphere restoran (Kenkman dan Hooper, 2012). Penelitian ini mengindikasikan bahwa perubahan atmosphere dari sebuah fasilitas makan, dalam hal ini fasilitas makan di panti wreda yang dibentuk menjadi restaurant-style, dapat mempengaruhi persepsi dari para pelanggannya bahkan merubah 'rasa' yang dipancarkan. Kenkman dan Hooper (2012) juga menambahkan dalam simpulan bahwa dalam fasilitas makan seperti di panti wreda, arsitektur merupakan kuncinya. Fasilitas makan tersebut perlu diintegrasikan secara pasti dan untuk mencapai hal ini para penghuni perlu dilibatkan kedalam mekanisme pengambilan keputusan, kemudian reaksi mereka terhadap perubahan tertentu perlu dipegang sebagai pedoman untuk perbaikan.

Terdapat juga sebuah artikel yang memaparkan implikasi lain dari restaurant atmosphere. Berdasarkan US Restaurant Satisfaction Study yang dirilis oleh J. D. Power and Associates pada tahun 2010, Ruggless (2010) mengatakan bahwa walaupun dengan kondisi ekonomi saat ini, harga bukanlah segalanya untuk pelanggan restoran. Dari survey yang dilakukan terhadap 93,410 pelanggan pada lebih dari 100 restoran, ditemukan bahwa kepuasan pelanggan ditentukan dari pelayanan yang berkualitas dan juga atmosphere. J. D. Power and Associates merupakan sebuah perusahaan informasi pemasaran yang berbasis di Westlake Village, California. "While you may be able to capture some market share on a value-based strategy, you still have to pay attention to service and experience to have an overall positive outcome," ungkap Jim Howland, Senior Director of Hospitality Practice, J. D. Power and Associates (Rugless, 2010).

Studi lain dilakukan sebelumnya oleh Keyt, Yavas dan Riecken (1994) dengan perspektif yang berbeda. Dalam analisanya terhadap restaurant positioning, Keyt, Yavas dan Riecken (1994) menemukan bahwa atribut positioning untuk restoran yang paling menonjol adalah pelayanan, harga, kualitas makanan, atmosphere atau suasana restoran, dan variasi makanan atau menu selection. Dengan menggunakan metode Importance Performance Analysis, Keyt, Yavas dan Riecken (1994) menyatakan bahwa restaurant atmosphere berada dalam kategori 'the lost opportunity' atau kesempatan yang terlewatkan diantara atribut positioning lainnya. Restaurant atmosphere dapat diperhitungkan sebagai competitive advantage yang solid dan dalam temuannya diungkapkan bahwa satu hal yang dapat diperbaiki dari hal ini adalah pengembangan program komunikasi yang dapat memancarkan superior atmosphere dari restoran secara efektif.

\section{SIMPULAN}

Dari kajian pustaka yang telah dipaparkan, dapat ditarik sebuah simpulan bahwa penelitian untuk atmosphere dari sebuah restoran dapat dilihat dari berbagai perspektif. Atmosphere merupakan sebuah 'rasa' yang ditampilkan secara seketika oleh sebuah restoran terhadap pelanggannya dan terdapat berbagai aspek yang perlu diperhatikan untuk menentukan atmosphere tersebut. Atmosphere dari sebuah restoran dapat dinilai sebagai sebuah competitive advantage dan menjadi salah satu penentu kepuasan pelanggan. 


\section{DAFTAR PUSTAKA}

Davis, B., Lockwood, A., Pantelidis, I., \& Alcott, P. (2008). Food and Beverage Management. Oxford: Butterworth-Heinemann.

Hashim, F. A., Bibon, M. A., and Abdullah, R. P. S. R. (2011). Restaurant's atmospheric elements: what the customer wants. Journal of Asian Behavioral Studies, 1 (2).

Katsigris, C., \& Thomas, C. (2009). Design and Equipment for Restaurants and Foodservice. New Jersey: John Wiley \& Sons, Inc.

Kenkman, A., \& Hooper, L. (2012). The Restaurant within the Home: Experiences of a Restaurantstyle Dining Provision in Residential Homes for Older People. Quality in Ageing and Older Adults: 98-110.

Keyt, J. C., Yavas, U., \& Riecken, G. (1994). Importance-performance Analysis: A Case Study in Restaurant Positioning. International Journal of Retail and Distribution Management, 35.

Mueller, P. (2001). Success By Design: Restaurant Environment Just As Crucial As Good Food, Prompt Service. New York: Nation's Restaurant News.

Parpal, M. (2013). How to Create a Restaurant Concept. foodservicewarehouse.com. Retrieved from: http://www.foodservicewarehouse.com/education/how-to-start-a-restaurant/how-to-create-arestaurant-concept/c28302.aspx

Peck, C. (2008). A Lighthearted Restaurant Atmosphere Gives Your Guests a Much-needed Break from the Daily Grid. Nation's Restaurant News: 42-46.

Ramapuram, T. E., Batra, A. (2006). The effect of Restaurant Attributes on Customers' Overall Perception and Return Patronage: A Case Study of Ebony Restaurant, Bangalore India. Diakses dari http://www.journal.au.edu/journal_management/2006/jul06/jul06-article04effect.pdf

Robson, S. (2013, November). Implications; Strategies for Designing Effective Restaurants. Retrieved from www.informedesign.umn.edu.

Ruggless, R. (2010). J. D.Power Study Ranks Restaurant Satisfaction. Nation's Restaurant News, 8.

Sujatno, A. B. (2011). Hospitality: Secret Skill, Attitude and Performance for Restaurant Manager. Edisi Pertama. Yogyakarta: Penerbit ANDI.

UNWTO. (2013). Facts and Figures Edition Page. Retrieved November 08, 2013, from World Tourism Organization: http://www2.unwto.org/?q=facts/wtb.html

Walker, J. R. (2009). Introduction to Hospitality Operations. New York: Prentice Hall. 